\title{
Ingestive diurnal behaviour of grazing beef cattle
}

\section{Comportamento ingestivo diurno de bovinos de corte em pastejo}

\author{
Josilaine Aparecida da Costa Lima ${ }^{1 *}$; Henrique Jorge Fernandes ${ }^{2}$; Aline Gomes da \\ Silva $^{3}$; Gumercindo Loriano Franco ${ }^{3}$; Edneia Pereira Rosa ${ }^{1}$; Yasmin dos Santos \\ Falcão ${ }^{4}$; Luísa Melville Paiva ${ }^{2}$
}

\section{Highlights:}

The concentrate supplementation reduced grazing time.

The concentrate supplementation increased idle time.

The supplementation strategy affected the intake pattern of supplementation.

The castrated males remained lying longer when compared to the females.

The females remained longer in standing ruminating than the castrated males.

\begin{abstract}
Three experiments were conducted with the objective of evaluating the effects of supplementation (concentrate or mineral supplementation), supplementation strategy (continuous or strategic supplementation) and gender class on the ingestive and diurnal behaviour of grazing beef cattle. To evaluate the effect of the supplementation (Experiment 1) and the gender class (Experiment 3 ) on their diurnal behaviour, behaviour visualisations were performed by two people at observation stations outside the picket area with the aid of binoculars. The animal behaviour was classified as: supplement intake, grazing, water intake, standing ruminating, standing idle, lying ruminating, lying idle and walking. To evaluate the effect of the supplementation strategy on the ingestive behaviour of the supplement (Experiment 2), refusals of the supplement were weighed for six consecutive days at different times $(20,40,60,90,120,180,240,480$ and 1,440 minutes) after the concentrate was supplied. The intake of concentrate per animal, at each observation time, was calculated by subtracting the weight of the scraps at that time from the total weight of the batch of supplement provided on the day, and dividing the result by the number of animals in each batch. Finally, a logistic model was adjusted for each treatment. A 10\% significance level was adopted for all statistical procedures. Concentrate supplementation reduced the time that the animals spent grazing. The continuous supplementation strategy affected the uniformity of the supplement intake speed, without affecting the average speed or the total supplement intake. The gender class of the animals also influenced their diurnal behaviour, castrated males spent more time lying, compared to females. The specificities of cattle behaviour should be considered when delineating the supplementation of grazing cattle, since the type of supplement, previous supplementation and gender class interfere with their behaviour.
\end{abstract}

Key words: Concentrate Supplement. Ethology. Intake. Ruminating.

1 Discentes, Curso de Doutorado, Programa de Pós-Graduação em Ciência Animal, Universidade Federal do Mato Grosso do Sul, UFMS, Campo Grande, MS, Brasil. E-mail: josilainelima.zootecnia@yahoo.com.br; neiaros@hotmail.com

2 Profs., UEMS, Aquidauana, MS, Brasil.E-mail: henrique.uems@hotmail.com; lumelville@gmail.com

3 Profs., UFMS, Campo Grande, MS, Brasil. E-mail: alinegomesdasilva@rocketmail.com; gumercindo.franco@ufms.br

4 M.e, UEMS, Aquidauana, MS, Brasil. E-mail: yasmin_sfalcao2@hotmail.com

* Author for correspondence 


\section{Resumo}

O objetivo com este trabalho foi avaliar o efeito da suplementação (concentrada ou mineral), da estratégia de suplementação (contínua ou somente nas águas) e da classe de gênero dos animais sobre o comportamento ingestivo diurno de bovinos de corte em pastejo. Para avaliação do efeito da suplementação (Experimento 1) e da classe sexual dos animais (Experimento 3) sobre o comportamento diurno, foram realizadas visualizações do comportamento animal por dois observadores treinados em estação de observação ao lado dos piquetes onde encontravam-se os animais, com auxílio de binóculos. O comportamento animal foi classificado como: consumindo suplemento, pastejando, ingerindo água, em pé ruminando, em pé em ócio, deitado ruminando, deitado em ócio e caminhando. Para avaliação do efeito da estratégia de suplementação sobre o comportamento ingestivo de suplemento (Experimento 2), as sobras do suplemento foram pesadas durante seis dias consecutivos em diferentes horários $(20,40$, $60,90,120,180,240,480$ e 1.440 minutes) após o fornecimento de suplemento. e, para cada tratamento, ajustou-se um modelo logístico. O consumo de suplemento concentrado por animal, a cada tempo de observação foi calculado subtraindo-se o peso das sobras naquele momento do peso total do suplemento fornecido ao lote no dia, e dividindo-se o resultado pelo número de animais em cada lote. Por fim, ajustou-se um modelo logístico para cada tratamento. Adotou-se um nível de significância de $10 \%$ para todos os procedimentos estatísticos. O fornecimento de suplemento concentrado reduziu o tempo de pastejo. A suplementação concentrada contínua afetou a uniformidade da velocidade de consumo, sem afetar a velocidade média ou o total consumido de suplemento. A classe de gênero dos animais também influenciou seu comportamento diurno, machos castrados despenderam maior tempo deitados quando comparados às fêmeas. As especificidades do comportamento de bovinos devem ser consideradas ao delinear-se a suplementação de bovinos em pastejo, uma vez que o tipo de suplemento, a suplementação prévia e a classe de gênero interferem com o comportamento dos mesmos.

Palavras-chave: Consumo. Etologia. Ruminação. Suplemento. Concentrado.

\section{Introduction}

In grazing cattle production systems seasonal variation in the quality and quantity of forage produced may hinder the achievement of better productive indexes. An alternative used in order to equilibrate the nutritional supply at different times of the year is the supply of concentrate supplements, aiming at supplying the deficiencies of specific nutrients in defined seasons of the year. This concentrate supplementation, however, may affect animal behaviour, having repercussions on their performance (Moreno, Fischer, Monks, Gomes, \& Stumpf, 2008).

The behaviour of grazing animals may be affected by several factors inherent to the animal or plant (González, Manteca, Calsamiglia, SchwartzkopfGenswein, \& Ferret, 2012). Animal related factors include age, gender, live weight, physiological stage, body and sanitary conditions. When the behaviour of males and females is studied, it is generally noted that males, especially non-castrated males, tend to have shorter grazing periods than females, and are more likely to spend more time in rumination, which usually results in greater feed efficiency of males (Ítavo, Souza, Rímoli, Ítavo, \& Dias, 2008; P. B. Santos et al., 2018).

Plant factors, which include chemical composition and anatomical structure, determine the palatability and acceptability of the forage by the animal (Carvalho et al., 2007). Cattle have a certain level of dietary selection, which in turn may be affected by the physical and chemical characteristics of the feed. When grazing, these animals tend to prefer the upper stratum of the pasture, as it has more leaf. However, when pasture height is lower than ideal, cattle tend to lengthen grazing time and bite rate (Fonseca et al., 2013). Cattle use their tongue to seize fodder and when pasture height is reduced, seizure becomes more difficult, forcing the animal to extend its time and daily bits to compensate for 
this problem and to reach the required level of intake (Hodgson, 1990; Carvalho, Ribeiro, Poli, Moraes, \& Delagarde, 2001).

On the other hand, environmental and behavioural factors can influence intake and animal performance (Maggioni et al., 2009). Thus, awareness of the patterns of daytime animal behaviour, and how they are affected by changes in the production system, becomes important in order to guide the adequacy of management practices that can enable the increase of productivity (R. R. Silva et al., 2010; González et al., 2012).

In this context, the aim of this study was to assess the effect of the nutritional supplementation type and strategy and of the gender class concerning the ingestive diurnal behaviour of beef cattle on grazing.

\section{Material and Methods}

Three experiments were carried out in the beef cattle sector of the State University of Mato Grosso do Sul, at the University Unit of Aquidauana, MS, between June and January. All procedures involving animals were approved by the Animal Ethics Committee of the State University of Mato Grosso do Sul (no. 02/2016).

\section{Experiment 1}

The first experiment had as its objective the assessment of the supplementation effect (concentrate or mineral) on the diurnal behaviour of beef cattle on grazing. Twenty-four Nellore young bulls were used, with the mean initial weight of $384 \pm 15.7 \mathrm{~kg}$ and the mean initial age of $27 \pm$ 1.45 months. In the beginning of June, the animals were randomly divided and housed in two pickets of Panicum maximum cv. Mombaça, of 4.0 hectares each.

The treatments, supplemented with concentrate or mineral, were randomly distributed to the animals, resulting in 12 experimental units per treatment. The concentrate supplement was formulated with corn (92.4\%), soybean meal (4\%) and urea (3.6\%) to contain $28 \%$ crude protein $(\mathrm{CP})$ and $80 \%$ total digestible nutrients (TDN), and the amount of $0.5 \%$ of body weight was given daily at $10 \mathrm{~h} 00$. To correct the concentrate supplement, the animals were weighed monthly without fasting. The animals supplemented only with mineral received Real $\mathrm{H}$ $650^{\circledR}$ mineral mixture ${ }^{2}$ ad libitum (Real H, Campo Grande, MS). Both treatments had ad libitum access to water throughout the experiment.

For the correct identification of the animals, numbers were painted on their side. Behaviour visualisations were performed by two trained people at observation stations outside the picket area with the aid of binoculars. The observations were carried out during six days in the months of September and October, every five minutes, in a daily period of 12 hours, between $06 \mathrm{~h} 00$ and 18h00 (Mezzalira et al., 2011). Each pair of observers was replaced after four hours.

In the observations, the behaviour of the animals was classified as: supplement intake, water intake, grazing, walking, standing ruminating, lying ruminating, total ruminating time, standing idle, lying idle and total idle time (Mercês et al., 2012).

The supplement intake was considered the time the animals were observed in the trough consuming the concentrate or mineral supplement. Water intake was considered the time the animals were observed in the trough consuming water. Grazing activity included time spent searching and harvesting forage.

\footnotetext{
${ }^{2}$ Assurance levels of mineral mixture: minimum calcium, $211 \mathrm{~g} \mathrm{~kg}^{-1}$; maximum calcium, $221 \mathrm{~g} \mathrm{~kg}^{-1}$; minimum cobalt, $90 \mathrm{~g} \mathrm{~kg}{ }^{-1}$; minimum copper, $1,150 \mathrm{~g} \mathrm{~kg}^{-1}$; minimum sulfur, 3,000 $\mathrm{g} \mathrm{kg}^{-1}$; minimum fluorine, $650 \mathrm{~g} \mathrm{~kg}^{-1}$; minimum phosphorus, $65 \mathrm{~g} \mathrm{~kg}^{-1}$; minimum iodine, $90 \mathrm{~g} \mathrm{~kg}^{-1}$; minimum magnesium, $5,000 \mathrm{~g} \mathrm{~kg}^{-1}$; minimum manganese, $1,400 \mathrm{~g} \mathrm{~kg}^{-1} ;$ minimum selenium, $10 \mathrm{~g} \mathrm{~kg}$; minimum sodium, $106 \mathrm{~g} \mathrm{~kg}^{-1}$; minimum zinc, $2,500 \mathrm{~g} \mathrm{~kg}^{-1}$.
} 
Short displacements with head down looking for pasture were computed as grazing time. Walking was considered the time spent by the animals moving around the paddock with their heads held high, without consuming the pasture. Rumination was considered the time when the animals were observed ruminating, process of regurgitation and remastigation of the food bolus that promotes the breaking of the particles again, this time was subdivided into standing ruminating and lying ruminating. Idleness was considered the time when the animals were not grazing or ruminating, this includes the times of social activities. This time was also subdivided into standing idle and lying idle.

The total ruminating time was calculated as the sum of the times spent standing ruminating and lying ruminating. Similarly, total idle time was estimated by adding the times spent standing idle and lying idle.

The data were analysed considering the daily time spent in each activity (minutes) as repeated measures in time, in each animal, during the six days of observation. PROC MIXED procedure of SAS software (Statistical Analysis System, version 9.2) was applied for all statistical analyses. For all statistical procedures, $\alpha=0.10$.

\section{Experiment 2}

To evaluate the effect of the supplementation strategy (continuous supplementation or strategic supplementation) on the ingestive behaviour of beef cattle under grazing, 12 young bulls from Experiment 1 were used.

Six animals which began to receive the concentrate supplement in June were used (at the beginning of experiment 1), in the amount of $0.5 \%$ of body weight per day (continuous supplementation), adjusted every 30 days. The second treatment (strategic supplementation rainy season supplementation), involved six other animals participating in experiment 1 , but they only received mineral supplement ad libitum until the beginning of December.

In December, the same concentrate was then given daily to both treatments in the same proportion of their body weight ( $0.5 \%$ of body weight). The supply was always given at the same time, in the morning, at 10:00 h. The concentrate used had the same composition as the concentrate used in Experiment 1.

The evaluation of the ingestive behaviour occurred after a 30-day adaptation period after the beginning of the supply of the concentrate supplementation to the animals of the strategic supplementation treatment. For six consecutive days, the scraps from the supplement were weighed at the trough at $20,40,60,90,120,180,240$, 480 and 1,440 minutes after the concentrate was supplied. The intake of concentrate per animal, at each observation time, was calculated by subtracting the weight of the scraps at that time from the total weight of the batch of supplement provided on the day, and dividing the result by the number of animals in each batch.

For each treatment, a logistic model of type $\mathrm{Y}$ $=\mathrm{a} *\left(1-\mathrm{b} * \mathrm{e}^{(-\mathrm{k} * \mathrm{x})}\right)^{-1}$ was adjusted, where " $\mathrm{a}$ ", "b" and " $\mathrm{k}$ " are the parameters of the model, "e" is the basis of the natural logarithm, and $\mathrm{Y}$ and $\mathrm{X}$ are the variables. Parameter "a" represents the maximum limit of daily supplement intake by the animals of that treatment; parameter " $b$ " is linked to the estimates of intake close to the initial time and this parameter, which has no specific biological interpretation, is responsible for the format that the intake curve assumes (Sarmento et al., 2006) and parameter " $k$ " can be interpreted as the average intake rate (or speed) of the supplement.

This model was adjusted to describe the intake pattern of the concentrate supplement (Y, \% of body weight) in function of the intervening time since the supply was given (X, in minutes), for 24 hours, for each treatment. The models and each of their parameters were compared as suggested by 
Regazzi (2003). PROC NLIN procedure of SAS software (Statistical Analysis System, version 9.2) was used to adjust the curves for each treatment. For all statistical procedures, $\alpha=0.10$.

\section{Experiment 3}

The third experiment was designed to evaluate the effect of different gender classes on the diurnal behaviour of cattle, and was carried out during the month of January. Twelve Nellore cattle were used, six castrated males and six females, with the mean initial weight of $224 \pm 18.5 \mathrm{~kg}$ and the mean initial age of $16 \pm 1.27$ months.

The animals were housed in a picket of Brachiaria decumbens Stapf cv. Basilisk, with water and mineral mixture supplementation ad libitum with composition similar o Experiment 1. Observations of the diurnal behaviour of the animals were realized for six days, similarly to the observations described in Experiment 1. Also the calculation of the total ruminating time, total idle time, and time spent on each activity were estimated as previously described. The total standing time was calculated as the sum of the times spent standing ruminating and standing idle. Similarly, total lying time was estimated by adding the times spent lying ruminanting and lying idle.

The data were analysed considering the daily time spent in each activity (minutes) as repeated measures in time, in each animal, during the six days of observation. PROC MIXED procedure of SAS software (Statistical Analysis System, version 9.2) was applied for all statistical analyses. For all statistical procedures, $\alpha=0.10$.

\section{Results}

In the evaluation of the diurnal behaviour of cattle receiving concentrate or mineral supplementation (Experiment 1), except for the time of supplement intake, grazing time and idle standing time, diurnal activities did not present significant differences (Table 1). The time of concentrate supplement intake was approximately $38 \mathrm{~min} \mathrm{day}^{-1}$, greater than the time of mineral supplement intake, approximately

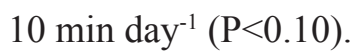

Table 1

Means, Standard error of the mean (SEM), and indicators of significance for diurnal behavioural activities of cattle supplemented under grazing

\begin{tabular}{|c|c|c|c|c|}
\hline \multirow{2}{*}{ Behaviour $^{1}$} & \multicolumn{2}{|c|}{ Supplementation } & \multirow{2}{*}{$\mathrm{SEM}^{2}$} & \multirow{2}{*}{$P$-Valor } \\
\hline & Mineral & Concentrate & & \\
\hline Supplement intake & 9.8 & 37.6 & 1.46 & $<0.001$ \\
\hline Water intake & 7.1 & 7.5 & 0.63 & 0.664 \\
\hline Grazing & 392.0 & 354.0 & 7.99 & 0.001 \\
\hline Walking & 20.8 & 22.8 & 1.70 & 0.423 \\
\hline Standing ruminating & 4.3 & 4.4 & 0.88 & 0.976 \\
\hline Lying ruminating & 43.7 & 42.7 & 5.90 & 0.901 \\
\hline Total ruminating time & 48.0 & 47.1 & 6.31 & 0.918 \\
\hline Standing idle & 51.3 & 59.6 & 3.00 & 0.054 \\
\hline Lying idle & 191.0 & 191.0 & 11.30 & 0.982 \\
\hline Total idle time & 242.0 & 251.0 & 12.60 & 0.628 \\
\hline
\end{tabular}

${ }^{1}$ minutes/day; ${ }^{2}$ Standard error of the mean. 
The diurnal grazing time observed for the animals receiving the concentrate supplementation was approximately 40 minutes less than the animals that received mineral supplementation $(\mathrm{P}<0.10)$. Most of this time (approximately $28 \mathrm{~min} \mathrm{day}^{-1}$ ) was used in the intake of the concentrate supplement or standing idle (approximately $8 \mathrm{~min} /$ day).
When evaluating the ingestive behaviour of beef cattle on grazing by using the logistic model in the supplement intake data (Experiment 2), a difference between the models of concentrate intake in animals receiving continuous or strategic supplementation $(\mathrm{P}<0.10$; Table 2) was observed.

Table 2

Estimates of the parameters of the prediction equations of the ingestive behaviour of the concentrate supplement and comparison of the equations and their parameters among the treatments

\begin{tabular}{lccc}
\hline \multirow{2}{*}{ Parameters } & \multicolumn{2}{c}{ Treatments } & \multirow{2}{*}{$P$-Valor } \\
\cline { 2 - 3 } & \multicolumn{2}{c}{ Strategic Supplementation } & Continuous Supplementation \\
\hline Complete model $^{1}$ & & & $<0.001$ \\
$\mathrm{~A}$ & 0.5079 & 0.4918 & 0.468 \\
$\mathrm{~B}$ & -2.2204 & -7.7803 & $<0.001$ \\
$\mathrm{~K}$ & 0.0146 & 0.0186 & 0.119 \\
\hline
\end{tabular}

${ }^{1}$ logistic model of type: Intake $=a^{*}\left(1-b^{*} e^{\left(-k^{*} \min \right)}\right)^{-1}$, where "Intake" is the supplement intake at a given time, in \% of the animal's body weight; "e" is the basis of the natural logarithm; "min" is the time from supplement delivery, in minutes; and "a", "b" and "k" are previously defined model parameters.

Analysing each parameter separately, it was observed that the animals of both treatments consumed the totality of the concentrate supplement provided daily (parameter "a" of Table 2 similar between treatments $(\mathrm{P}>0.10)$, and near $0.5 \%$ of body weight which was the total provided). The " $k$ " parameter, also similar between treatments $(\mathrm{P}>0.10)$, showed that the mean intake velocity of the supplement was the same, regardless of the supplementation strategy (continuous or strategic supplementation).

The "b" parameter has not biological interpretation, but is responsible for the format that the intake curve assumes. As the value of this parameter increases, the initial intake of the supplement increases, and more uniform is the intake pattern until the maximum daily consumption is reached. In fact, when this parameter assumes smaller values, the supplement intake curve takes a form closer to an "S", while with higher values, this model shows a pattern closer to a continuous intake until reaching the maximum plateau of the day (as in a linear-plateau curve). This could be seen here, where the lower value $(\mathrm{P}<0.10)$ of parameter " $\mathrm{b}$ " in the continuous supplementation intake curve leads to a lower initial feed intake and a less straight curve until the maximum feed intake of the day is reached (Figure 1). This parameter was the only one to show significant difference between the supplementation systems, thus causing it to be the main responsible for the difference in the daily supplementary intake pattern (Table 2).

The gender class did not affect the times of supplement intake, water intake, grazing, walking, standing idle and total idle time (Experiment 3, $\mathrm{P}>0.10$, Table 3 ). Regarding the total standing time, the females spent 117 minutes, 16 minutes more $(\mathrm{P}<0.10)$ than the castrated males (101 minutes). In this standing period, $27.5 \%$ (32.2 minutes) were spent on rumination, while castrated males spent only $23.7 \%$ (23.9 minutes) of their standing time with rumination $(\mathrm{P}<0.10)$. 


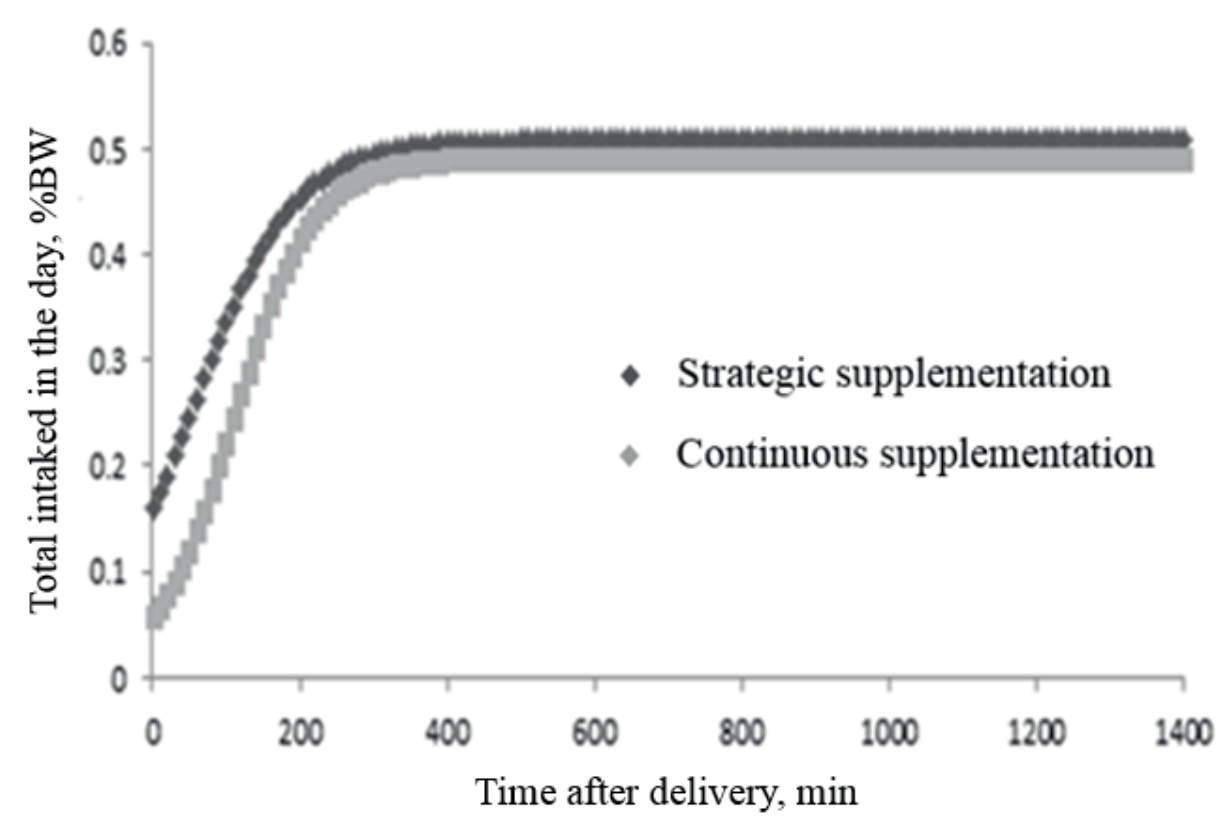

Figure 1. Daily intake of supplements (\% body weight) by cattle submitted to two supplementation strategies.

Table 3

Means, standard error of the mean (SEM), and indicators of significance for diurnal behavioural activities of cattle of different genders under grazing

\begin{tabular}{lcccc}
\hline \multirow{2}{*}{ Behaviour $^{1}$} & \multicolumn{2}{c}{ Gender } & \multirow{2}{*}{ SEM $^{2}$} & \\
\cline { 2 - 3 } & Females & Castrated Males & & \\
\hline Supplement intake & 4.1 & 5.0 & 0.65 & 0.421 \\
Water intake & 1.9 & 2.3 & 0.37 & 0.385 \\
Grazing & 420.0 & 409.0 & 4.50 & 0.152 \\
Walking & 63.0 & 60.0 & 1.70 & 0.212 \\
Standing ruminating & 32.2 & 23.9 & 2.57 & 0.059 \\
Lying ruminating & 63.8 & 82.7 & 3.03 & 0.002 \\
Total ruminating time & 96.1 & 107.0 & 3.63 & 0.072 \\
Standing idle & 84.4 & 76.8 & 3.05 & 0.119 \\
Lying idle & 50.3 & 59.9 & 2.92 & 0.057 \\
Total idle time & 135.0 & 137.0 & 3.82 & 0.780 \\
Total standing time & 117.0 & 101.0 & 3.51 & 0.012 \\
Total lying time & 114.0 & 143.0 & 3.41 & $<0.001$ \\
\hline
\end{tabular}

${ }^{1}$ minutes/day; ${ }^{2}$ Standard error of the mean.

The animals spent, on average, approximately $18 \%$ of the daytime lying (around 129 minutes). The castrated males remained lying longer when compared to the females $(\mathrm{P}<0.10)$. The males spent more time idle and more time ruminating comparing to the females ( $\mathrm{P}<0.10)$, with $41.9 \%$ of their time lying idle (59.9 minutes) and $57.8 \%$ ruminating (82.7 minutes). While females spent $44.1 \%$ of 
their time lying idle (50.3 minutes) and 56\% lying ruminating (63.8 minutes).

Rumination consumed approximately $14 \%$ of the diurnal period of the animals, and $72 \%$ of this activity was developed while the animals were lying. The castrated males spent approximately 11 minutes more ruminating than the females $(\mathrm{P}<0.10)$.

\section{Discussion}

When supplemented with concentrate, bovines usually spend more time consuming concentrate supplement when compared to the intake of mineral supplements (Table 1). This effect can be explained by the specificities of each supplement, since the mineral supplement intake is restricted because of its high sodium content when compared to the concentrate supplementation.

The length of stay of the animals in the trough, according to Cabral, Bauer, Cabral, Souza and Benez (2011), can be influenced by the percentage of nutrients in the supplement offered. These authors observed that animals receiving supplement with $20 \%$ of crude protein, besides remaining for a longer time in the trough when compared to the animals of the control treatment (mineral supplement) and the treatment animals receiving supplement containing $40 \%$ crude protein, still consumed more amounts of supplement.

When animals are supplemented, new variables interfere with the animal's diurnal behaviour. Bovines, just like other animals, seek to maintain food intake according to their nutritional needs and adjust their behaviour in response to changes in the environment, dividing the time between grazing activities, rumination, social interactions and idleness (Hodgson, 1990; Martins et al., 2012).

The longer idle standing time of animals supplemented with concentrate may be linked to a longer digestion time $(\mathrm{P}<0.10)$. The supplementation of cattle on grazing with concentrates tends to improve the ruminal environment, which improves the animal's ability to digest the diet (Detmann, Valente, Batista, \& Huhtanen, 2014). However, the absence of a significant effect on the total time of rumination and idleness $(\mathrm{P}>0.10)$ indicates that this effect may involve complex metabolic mechanisms, whose reflexes on animal behaviour cannot be easily observed.

When the ingestive behaviour was assessed, it was observed that continuously supplemented animals showed a slower intake immediately after the supply, followed by a more rapid intake in the following hours, whose speed was reduced until the total daily intake was reached. On the other hand, animals fed only by the strategic supplementation, showed a more uniformly distributed intake pattern, at a more constant speed, higher than the initial velocity and lower than the final speed observed for the treatment that received continuously concentrate supplementation.

Thus, despite the average intake velocity (parameter "k", Table 2), the intake pattern differed exactly by the variability of this velocity within the period, which was evidenced by the difference in parameter "b" (Table 2). Therefore, although this parameter does not have a direct biological interpretation, it was able to reflect a more specific and subtle phenomenon than the variation of the average speed of intake by the animals of the different treatments.

When evaluating three levels of urea in the diet $(0,4$ and $8 \%)$ A. G. Silva et al. (2008) observed an intake curve format similar to the one obtained in this study. Assessing the parameters alone, the authors also observed differences in parameter " $b$ ", caused by the addition of urea in the concentrate, which also affected the average rate of intake of the same (parameter " $k$ ").

As the animals that were supplemented only by strategic supplementation suffered moderate nutritional restriction in the dry period prior to the experiment, they were more anxious to consume concentrate even after 30 days of adaptation. This 
could be seen in the highest initial supplement intake and in the more linear (direct) pattern of the intake from the initial moment until it reaches the maximum daily consumption plateau of these animals, while the animals already receiving concentrated supplementation since the dry season showed a lower initial intake of supplement and a longer intake pattern during the day until they reach the plateau.

The gender of the animals (experiment 3), in cattle production studies, it is generally observed a higher weight gain in males is generally observed, in relation to females. This difference in weight gain may be related to the difference in the body composition of the animals (Beef Cattle Nutrient Requirements Model [BCNRM], 2016) and also to the lower energy expenditure of males with physical activities. As observed in this study, castrated males remained longer ruminating, idling and lying when compared to females.

In study evaluating different gender of cattle (G. P. Santos, 2014) noticed that males had higher food intake in a shorter feeding time, and a longer time for rumination. This indicates a lower energy expenditure in the feeding of males compared to females, and using the time in a better rumination, for a better break of the food, with better availability and better utilization of nutrients.

According to Missio et al. (2010), the increase in idleness time results in decreased physical activity, reducing energy expenditure and may contribute to greater efficiency in utilizing dietary nutrients and higher animal performance.

\section{Conclusion}

The results of the present study show that bovine behaviour specificities should be considered when delineating supplementation for grazing cattle, since the type of supplement, previous supplementation and gender class interfere with their behaviour.

\section{Acknowledgements}

The authors would like to thank the Coordenação de Aperfeiçoamento de Pessoal de Nível Superior Brasil (CAPES) - Finance Code 001, which partly financed this study and would also like to thank the Fundação de Apoio ao Desenvolvimento do Ensino, Ciência e Tecnologia do Estado de Mato Grosso do Sul (FUNDECT) and the Conselho Nacional de Desenvolvimento Científico e Tecnológico (CNPq) for their financial support to this study.

\section{References}

Beef Cattle Nutrient Requirements Model (2016). Nutrient requirements of beef cattle (8nd Revised Edition). Washington, DC: The National Academies Press.

Cabral, H. A. C., Bauer, M. O., Cabral, C. E. A., Souza, A. L., \& Benez, F. M. (2011). Comportamento ingestivo diurno de novilhos suplementados no período das águas. Revista Caatinga, 24(4), 178-185. doi: 19832125

Carvalho, P. C. F., Kosloski, G. V., Ribeiro, H. M. N., Fº, Reffatti, M. V., Genro, T. C. M., \& Euclides, V. P. B. (2007). Avanços metodológicos na determinação do consumo de ruminantes em pastejo. Revista Brasileira de Zootecnia, 36, (Supl),151-170. doi: 10.1590/S1516-35982007001000016

Carvalho, P. C. F., Ribeiro, H. M. N., Fº, Poli, C. H. E. C., Moraes, A., \& Delagarde, R. (2001). Importância da estrutura da pastagem na ingestão e seleção de dietas pelo animal em pastejo. Anais da Reunião Anual da Sociedade Brasileira de Zootecnia, Piracicaba, SP, Brasil, 38.

Detmann, E., Valente, E. E. L., Batista, E. D., \& Huhtanen, P. (2014). An evaluation of the performance and efficiency of nitrogen utilization in cattle fed tropical grass pastures with supplementation. Livestock Science, 162, 141-153. doi: 10.1016/j. livsci.2014.01.029

Fonseca, L., Carvalho, P. C. F., Mezzalira, J. C., Bremm, C., Galli, J. R., \& Gregorini, P. (2013). Effect of sward surface height and level of herbage depletion on bite features of cattle grazing Sorghum bicolor swards. Journal of Animal Science, 91,(9), 1-9. doi: 10.2527/jas2013-5602 
González, L. A., Manteca, X., Calsamiglia, K. S., Schwartzkopf-Genswein, K. S., \& Ferret, A. (2012). Ruminal acidosis in feedlot cattle: Interplay between feed ingredients, rumen function and feeding behaviour (a review). Animal Feed Science and Technology, 172(1-2), 66-79. doi: 10.1016/j. anifeedsci.2011.12.009

Hodgson, J. (1990). Grazing management: science into practise. Inglaterra: Longman Handbooks in Agriculture.

Ítavo, L. C. V., Souza, S. R. M. B. O., Rimoli, J., Ítavo, C. C. B. F., \& Dias, A. M. (2008). Comportamento ingestivo diurno de bovinos em pastejo contínuo e rotacionado. Archivos de Zootecnia, 57, 43-52. doi: 0004-0592

Maggioni, D., Marques, J. A., Rotta, P. P., Zawadzki, F., Ito, R. H., \& Prado, I. N. (2009). Ingestão de alimentos. Semina: Ciências Agrárias, 30(4), 963974. doi: 10.5433/1679-0359.2009v30n4p963

Martins, S. C. S. G., Rocha, V. R., Jr., Caldeira, L. A., Barros, I. C., Silva, G. W. V., Costa, M. D.,... Souza, A. S. (2012). Comportamento ingestivo de vacas mestiças alimentadas com diferentes volumosos. Revista Brasileira de Ciência Veterinária, 19(1), 1320. doi: 10.4322/rbcv.2014.072

Mercês, L. M., Marques, J. A., Barbosa, L. P., Brandão, T. O., Garcia, M. P., \& Costa, A. K. A. (2012). Horário alternativo de ordenha e o comportamento ingestivo de vacas mestiças leiteiras em sistema de produção a pasto. Acta Scientiarum. Animal Sciences, 34(2), 197-202. doi: 10.4025/actascianimsci.v34i2.12476

Mezzalira, J. C., Carvalho, P. C. F., Fonseca, L., Bremm, C., Reffatti, M. V., Poli, C. H. E. C., \& Trindade, J. K. (2011). Aspectos metodológicos do comportamento ingestivo de bovinos em pastejo. Revista Brasileira de Zootecnia, 40(5), 1114-1120. doi: 10.1590/S151635982011000500024

Missio, R. L., Brondani, I. L., Alves, D. C., Fo., Silveira, M. F., Freitas, L. S., \& Restle, J. (2010). Comportamento ingestivo de tourinhos terminados em confinamento, alimentados com diferentes níveis de concentrado na dieta. Revista Brasileira de Zootecnia, 39(7), 1571-1578. doi: 10.1590/S151635982010000700025
Moreno, C. B., Fischer, V., Monks, P. L., Gomes, J. F., \& Stumpf, W., Jr. (2008). Comportamento ingestivo diurno de novilhas Jersey sob suplementação com farelo de milho em pastagem de azevém anual. Revista Brasileira de Zootecnia, 37(3), 487-493. doi: 10.1590/S1516-35982008000300014

Regazzi, A. J. (2003). Teste para verificar a igualdade de parâmetros e a identidade de modelos de regressão não-linear. Revista Ceres, 50(287), 9-26. doi: $2854 / 710$

Santos, G. P. (2014). Eficiência alimentar, parâmetros sanguíneos e comportamento ingestivo de machos e fêmeas da raça Nelore. Dissertação de mestrado, Instituto de Zootecnia, Nova Odessa, SP, Brasil.

Santos, P. B., Santana, H. A., Jr., Araújo, M. J., Oliveira, A. P., Santana, E. O. C., \& Mendes, F. B. L. (2018). Feeding behavior of categories of feedlot-finished beef cattle. Acta Scientiarum. Animal Sciences, 40, 1-5. doi: 10.4025/actascianimsci.v40i1.35528

Sarmento, J. L. R., Regazzi, A. J., Souza, W. H., Torres, R. A., Breda, F. C., \& Menezes, G. R. O. (2006). Estudo da curva de crescimento de ovinos Santa Inês. Revista Brasileira de Zootecnia, 35(2), 435442. doi: 10.1590/S1516-35982006000200014

Silva, A. G. da, Fernandes, H. J., Lopes, S. A., Rocha, A. A., Figueiras, J. F., Detmann, E., \& Biancardi, G. F. (2008). Comportamento ingestivo de bovinos de corte a pasto suplementados com concentrados contendo diferentes níveis de ureia. Anais da Reunião Anual da Sociedade Brasileira de Zootecnia, Lavras, MG, Brasil, 45.

Silva, R. R., Prado, I. N., Silva, F. F., Almeida, V. V. S., Santana, H. A., Jr., Queiroz, A. C., Barroso, D. S. (2010). Comportamento ingestivo diurno de novilhos Nelore recebendo níveis crescentes de suplementação em pastejo de capim-braquiária. Revista Brasileira de Zootecnia, 39(9), 2073-2080. doi: 10.1590/S1516-35982010000900028 